\title{
MADRASAH DAN SEJARAH SOSIAL PENDIDIKAN ISLAM
}

\author{
Fitrijah Hidajati \\ Universitas Muhammadiyah Sidoarjo \\ Email: fitrijahhidajati@gmail.com \\ Desy Wulandari \\ Universitas Muhammadiyah Sidoarjo \\ Email: desiwoelan@gmail.com \\ Abdul Kholiq \\ Universitas Muhammadiyah Sidoarjo \\ Email: abaykholiq@gmail.com \\ Choirul Mahfud \\ Institut Teknologi Sepuluh Nopember Surabaya \\ Email: choirulmahfud@gmail.com
}

\begin{abstract}
Madrasas in Indonesia have grown and developed to become a supplement to the development of pesantren considered to be focused on religious learning, but learning is still minimal, plus religious. To this day, the existence of madrassas cannot be separated from the design plan to develop better the activities of obtaining religious knowledge either at home, prayer room, boarding school or mosque. From this it is known, that madrasa institutions have undergone curriculum and other updates. The presence of madrasa is seen as the main indicator in the positive development and progress of progress in the social history of Islamic education.
\end{abstract}

Keywords: Madrasah, Portrait of Social History, Islamic Education

\begin{abstract}
Abstrak
Madrasah di Indonesia tumbuh dan berkembang sedikit banyak menjadi suplemen perkembangan pesantren dinilai fokus pada pembelajaran agama, namun masih minim akan pembelajaran umumnya plus keagamaan. Hingga hari ini, keberadaan madrasah tidak bisa dipisahkan dari runtutan rancangan untuk mengembangkan lebih baik mengenai aktivitas mendapatkan ilmu agama baik dirumah, musholla, pesantren ataupun masjid. Dari sini diketahui, bahwa kelembagaan madrasah sudah mengalami pembaruan kurikulum dan lainnya. Kehadiran madrasah dipandang sebagai indikator utama dalam perkembangan positif dan majunya prestasi kemajuan sejarah sosial pendidikan Islam.
\end{abstract}

Kata Kunci: Madrasah, Potret Sejarah Sosial, Pendidikan Islam

Nur El-Islam, Volume 6, Nomor 1, April 2019 


\section{A. Pendahuluan}

Dewasa ini, pendidikan Islam sangat menjamur. Segala macam model pendidikan telah berdiri di sentaro negeri ini, seuatu yang membanggakan bagi umat Islam Indonesia dengan banyaknya pendirian lembaga-lembaga pendidikan Islam baru tersebut. ${ }^{1}$ Masyarakat bisa memiliki pilihan sesuai kebutuhan dan harapan agar dapat memenuhi keinginan generasi penerusnya sesuai dengan kapasitas kompetensi individu dan bakatnya untuk bisa berkembang menjadi generasi penerus pada perjuangan untuk agama, umat, bangsa dan Negara Indonesia Kesatuan Republik Indonesia.

Sebagai makhluk sosial yang selalu mengharapkan segala sesuatu yang memudahkan hidupnya, tentunya dengan mengggunakan segala macam potensi yang ada padanya, setiap orang akan berusaha maju dan berkembang menuju kekuatan lahir batin agar dapat menumbuhkan jasmani dan rohani sebagai alat untuk mensukseskan pendidikan terutama pendidikan Islam.

Munculnya lembaga pesantren dan madrasah ditandai dengan berkembangnya pendidikan dalam Islam yang berorientasi pada penguatan basis lembaga pendidikan Islam. ${ }^{2}$ Keberadaan pesantren tidak asing di kalangan masyarakat jika lembaga pendidikan selalu selaras dengan masyarakat di sekitarnya. Pemberian apresiasi dan dorongan masyarakat dapat menjadi acuan dalam setiap aktivitas yang dilakukan di pesantren. Dengan demikian, pendidikan madrasah akan mengalami kemajuan yang sangat cepat, sehingga banyak bermunculan sekolah modern seperti madrasah Ibtidaiyah, Tsanawiyah dan Aliyah yang dipercayai mampu memudahkan santri atau pelajar untuk belajar di madrasah sesuai tingkatannya.

Sejauh ini masyarakat memberikan penilaian yang kurang baik pada kualitas pendidikan madrasah. Namun dalam perkembangannya, stakeholder madrasah melakukan upaya-upaya untuk meningkatkan

\footnotetext{
1 Muhaimin, Arah Baru Pengembangan Pedidikan Islam: Pemberdayaan, Pengembangan kurikulum hingga Redefinisi Islamisasi Pengetahuan, (Bandung: Nuansa, 2003), h. 88-91.

${ }^{2}$ Azyumardi Azra, Historiografi Islam Kontemporer: Wacana, Aktualitas dan Aktor Sejarah, (Jakarta: Gramedia Pustaka Utama, 2002), h. 112-118.
} 
kualitas agar citra madrasah tidak selalu buruk di mata masyarakat. Madrasah, pesantren atau sekolah Islam memiliki peran untuk mengembangkan strategi dalam mengolah manajemen yang didefinisikan sebagai kumpulan keputusan atau tindakan untuk menghasilkan perumusan dan pelaksanaan rencana-rencana dalam mencapai sasarannya.

Sejarah pendidikan Islam perlu dijadikan referensi oleh umat Islam sendiri agar bisa dipahami sebagai tolak ukur kemajuan pendidikan Islam yang pernah mengalami masa kejayaan. Dengan penemuan berbagai macam keilmuan yang menjadikan manusia unggul pada masa kejayaan Islam itu, potret kejayaan pendidikan itu telah terukir dengan tinta emas yang menumbuhkan masyarakat cerdas dan berakal sehat. Dengan adanya masyarakat berakal sehat, akhirnya menimbulkan kehidupan sosial yang aman, tentram dan damai sebagai kunci dari terwujudnya masyarakat adil dan makmur.

Proses kebutuhan untuk saling belajar antara orang satu dengan lainnya, kelompok satu dengan lainnya membutuhkan belajar terintegrasi sesuai dengan tuntutan dan kebutuhan zaman yang dinamakan belajar yang menunjukkan pengaruh-pengaruh positif dari kelompok atau individu lainnya. Slamet Imam Santoso menyebut dengan sebutan pendidikan. Manusia sebagai pembelajar yang setiap saat dapat stimulus dari luar, secara langsung dan tidak langsung, bisa belajar dari fenomesa sosial yang ada. Hal ini bila dilembagakan di dalam kelompok belajar membutuhkan lembaga pendidikan yang menaungi segala macam kebutuhan keilmuan untuk manusia pembelajar. Manusia pembelajar yang sempurna akan membentuk lingkungan akal sehat. Menurut Noor Syam, manusia akan mengalami peningkatan kepribadian jika menguasai pendidikan berbudaya kreatif dan produktif untuk menghasilkan suatu kebudayaan. Sehingga pendidikan memiliki tujuan dapat membangun masyarakat yang berbudaya atau menjaga manusia supaya berkebudayaan. ${ }^{3}$ Dengan menjadi manusia berkebudayaan dan berakal sehat yang dapat

${ }^{3}$ M. Noor Syam, Filsafat Pendidikan dan Dasar Pendidikan Pancasila, (Surabaya: Usaha Nasional, 1986), h. 17-21. 
menyesuaiakan kebutuhan zaman, manusia bisa sukses dalam kehidupan di dunia dan akhirat. Manusia bisa melihat dan mengikuti perkembangan zaman di masa global dengan baik meskipun ada banyak tantangan pada era global ini dengan segala macam aspek sosialnya.

Tolak ukur dari luar mengaitkan pada jalannya era globalisasi dan isu yang terkait oleh masalah masyarakat sosial, majunya teknologi, bangkitnya industri dan budaya secara terus menerus, serta berkembangnya pendidikan tingkat dunia, itu semua memiliki banyak hubungan sebab akibat. Misalnya, akibat dari globalisasi, bisa berdampak pada tergesernya pola hidup rakyat di bidang pertanian dan perdagangan tradisional beralih jadi rakyat keindustrian serta perniagaan modern. Hal ini nampak terdeteksi di WTO, APEC, ASEAN, dan AFTA. Tantangan eksternal dikaitkan juga pada kuatnya ekonomi Internasional, adanya keterlibatan dan akibat teknosains serta kualitas, modal, hingga perbaikan di bidang kelembagaan pendidik. Ikut sertanya Indonesia dalam studi Internasional pada TIMSS dan program PISA dimulai tahun 1999 merupakan bukti yang dicapai oleh anak Indonesia kategori kurang baik dari adanya pengajuan laporan.

Aktivitas umat Islam yang berpedoman kepada Al-Qur'an tentunya apa yang dilakukan manusia sudah tertulis di dalam AlQur'an. Dalam Al-Qur'an ditegaskan bahwa Allah SWT menjadikan makhluknya supaya memiliki tujuan hingga akhir atau perolehan dari kegiatan bentuk ketaatan pada-Nya (QS. Al-Dzariyat: 56). Dalam hal ini, aktivitas yang dimaksudkan dalam Al-Qur'an menerangkan bahwa manusia adalah Khalifah di bumi ini. Sebagai khalifah yang memiliki Akhlaq tinggi dan menurut Abuddin Nata (QS. Al-Baqarah: 30 dan Hud: 16), bahwa: Urgensi pendidikan akhlak bagi remaja setidaknya ada empat faktor, pertama: Pentingnya pembentukan generasi bangsa yang kuat karena pepatah mengatakan pemuda di masa ini adalah pemimpin di masa mendatang, kedua: Pembinaan akhlak mulia adalah hakikat pembelajaran agama, menurut Fazlur Rahman prinsip agama Islam adalah terjadinya hubungan baik kepada Allah (habl Min Allah) dan terciptanya hubungan yang harmonis kepada sesama manusia (habl Min al-Nas). Ketiga, Akhlak mulia dipengaruhi oleh lingkungan 
keluarga, sekolah dan masyarakat sekitar. Keempat, Pendidikan agama di usia remaja sangatlah penting karena usia remaja berada dalam usia goncangan jiwa.

Pada pasal 1 No 1 Undang-Undang Tahun 2003 No 20 telah dipaparkan mengenai Sistem Pendidikan, yakni upaya kesadaran yang terstruktur dalam perwujudan kondisi belajar dan kegiatan pembelajaran supaya murid selalu semangat menambah perkembangan kemampuan dirinya sendiri. Hal ini berhubungan dengan kekuatan spiritual agama, kontrol diri, karakter pribadi, pemikiran cerdas, sikap tingkah laku mulia serta bakat yang dibutuhkan seseorang maupun kelompok hingga menyeluruh.

Dalam Pasal 6 No.1 PP. 2005 No.19 dikemukakan bahwa perangkat rancangan belajar atau disebut kurikulum termasuk bagian pendidikan pada umumnya, keguruan serta difokuskan di tingkatan dasar, SMP, meliputi pendidikan kewarganegaraan, aktivitas belajar keagamaan, karakter diri, pemikiran yang cerdas, keindahan, lahiriyah, kesehatan, hingga teknologi (PP RI No 19: 2005). Capaian pendidikan akhlak mulia serta agama adalah: membentuk murid menjadi orang taat keimanan serta bertaqwa pada Allah SWT dan memunyai akhlak terpuji. Dalam kaitan ini meliputi moral, sikap tingkah laku yang tidak melanggar, atau berbudi luhur dalam pencapaian pembelajaran agama. Salah satu sistem pendidikan luar sekolah yang dikenal yakni pesantren. Unsur pendidikan mencakup beberapa subsistem yang saling mengait tujuannya. Karena madrasah bagian dari sistem pendidikan, maka secara otomatis memenuhi kriteria dari sistem tersebut.

\section{B. Pembahasan}

Etimologi Kata Madrasah berawal dari Bahasa Arab menyatakan setting tempat (dzaraf), dari kata dasar: Darasa, Yadrusu, Darsan, serta Madrasatan yang memiliki pengertian Tempat menimba ilmu untuk pelajar atau diartikan sebagai jalan (Thariq). Penerapannya dimisalkan 
ini merupakan jalan kenikmatan. Lalu frasa Midras diartikan referensi yang dipahami atau wadah untuk belajar. ${ }^{4}$

Dari uraian di atas, madrasah merupakan wadah atau tempat belajar ilmu pengetahuan dan keislaman yang berkembang pada masanya. Madrasah juga sebagai wujud dari pengembangan masjid. Semakin banyaknya masyarakat yang ingin mendalami Islam, menjadikan masjid-masjid penuh halaqoh. Pada masing-masing halaqoh terdengar perdebatan lebih kurangnya dari pengajar dan murid dalam runtutan pembelajaran yang menyebabkan keramaian dan mengusik umat yang menjalankan ibadah.

Sebagai lembaga pendidikan Islam, perkembangan madrasah sejalan dengan proses masuknya Islam di Indonesia. Perubahan madrasah pada tingkatan dan sifatnya, senada dengan perihal berkembangnya bangsa mulai abad penjajahan, kesultanan, hingga kemerdekaan. Perubahan dan perkembangan tersebut antara lain terbentuk mulai awal, meliputi pengajaran agama Islam di rumah, mushalla, langgar serta masjid, berubah fungsi menjadi sebuah institusi resmi layaknya berupa madrasah yang dikenal saat ini.

Madrasah merupakan lembaga pendidikan Islam yang usianya lebih muda dari pada pesantren. Lahirnya madrasah Manbaul Ulum tahun 1905 dan sekolah Adabiyah tahun 1909 merupakan gagasan dari pembaharuan pendidikan sebelumnya. Tetapi kurang dari satu tahun sekolah Adabiyah ditutup dan dipindahkan ke Padang. Sebab-sebab kegagalannya antara lain karena adanya perlawanan di Padang Panjang terhadap pendirian sekolah tersebut, sehingga pada awal berdirinya hampir tidak ada muridnya. ${ }^{5}$

Sekolah Adabiyah ini mempunyai semangat pembaharuan yang cukup revolusioner di zamannya. Hal ini disebabkan oleh tiga faktor: Pertama, terjadinya dialektika antara pemikiran Abdullah Ahmad degan corak pemikiran kaum pembaharu Timur Tengah (Muhammad Abduh). Kedua, terjadinya kontak intensif antara Abdullah dengan

\footnotetext{
${ }^{4}$ Abuddin Nata, Modernisasi Pendidikan Islam di Indonesia, (Jakarta: UIN Jakarta Press, 2006), h. 50.

${ }^{5}$ Hasbullah, Sejarah Pendidikan Islam di Indonesia: Lintasan Sejarah Pertumbuhan dan Perkembangan, (Jakarta: PT. Raja Grafindo Persada, 1999), h. 168.
} 
Syeikh Thahir Jalaludin; muslim Singapura dianggap sebagai pencetus pertama di Negara Indonesia yang disebabkan banyak munculnya faham dari Mochammad Abduh serta mempublikasikan rancangan pendirian madrasah modern melalui media cetak Al-Iman yang beredar di Singapura dengan kisaran tahun 1906 Masehi. Ketiga, tumbuhnya semangat untuk mengikuti jejak langkah penyelenggaraan pendidikan di sekolah gubernemen Padang yang sangat tertib dan baik. ${ }^{6}$ Sistem pendidikan madrasah di Indonesia selalu menunjukkan inovasinya untuk mempertahankan keberadaannya.

Jika dibandingkan dengan SD,SMP, SMA/K, atau Universitas, perkembangan madrasah maju lebih dahulu. Karena madrasah sebagai sarana atau media strategis bagi kyai dalam menyampaikan ajaran Islam. Selain itu, para raja muslim menyampaikan kegiatan kenegaraan dan keagamaannya. Menurut Muhaimin, Madrasah Muhammadiyah (Kweekschool Muhammadiyah) didirikan pada tahun 1918 di Yogyakarta. Kemudian Kweekschool Muhammadiyah berubah nama menjadi Madrasah Mu'alimin, sebagai wujud angan-angan dari proses gebrakan baru Pendidikan dalam Islam yang dimotori oleh $\mathrm{KH}$ Ahmad Dahlan. ${ }^{7}$ Lebih lanjut Muhaimin menjelaskan bahwa cita-cita K.H. Ahmad Dahlan atau cita-cita pendidikan Muhammadiyah itu sendiri menurut kesimpulan Wirjosukarto (1985) adalah menjadikan manusia sebagai muslim yang (1) berprilaku baik dan taat terhadap agama; (2) mempunyai pola pikir yang luas serta akademisi dalam ilmu umum; dan (3) mampu memperjuangkan kehidupan yang layak dalam masyarakatnya. Dalam hal ini, Muhaimin menyatakan bahwa dua sistem yang digunakan dalam pengembangan pendidikan tersebut, adalah: (1) Lembaga mengacu pada gubernemen yang ditambah dengan pendidikan agama; (2) Memberikan pengajaran lebih banyak ilmu agama dalam madrasah. ${ }^{8}$

Adapun syarat sebuah madrasah yang ingin diakui oleh Kementrian Agama ialah sebagai berikut: a) keberadaannya diakui

\footnotetext{
${ }^{6}$ Muhaimin, Arah Baru Pengembangan Pedidikan Islam, Ibid, h. 19-20.

${ }^{7}$ Ibid, h. 20.

${ }^{8}$ Ibid, h. 22.
} 
minimal selama satu tahun. b) Mempunyai susunan kelompok yang terstruktur; c) Masyarakat menghendaki berdirinya madrasah tersebut; d) Selain ilmu agama, madrasah tersebut dapat mengaplikasikan pembelajaran umum minimal 30\% dari total jam pengajaran seminggu. ${ }^{9}$

Berdasarkan dari ketetapan itu, lembaga yang disebut madrasah merupakan tempat memperoleh pendidikan serta pengetahuan agama Islam yang menjadi pusat dalam pembelajarannya. Merujuk pada ketetapan tersebut, tahap pendidikan yang diperoleh dari madrasah disusun antara lain: a). Madrasah rendah (sekarang disebut Madrasah Ibtidaiyah), yaitu madrasah yang terdapat muatan pengetahuan serta pendidikan agama Islam sebagai pusat pembelajaran dan pengajaran, capaiannya selama enam tahun. b). Madrasah lanjutan tingkat pertama disebut juga dengan Tsanawiyah merupakan madrasah untuk menampung siswa lulusan dari madrasah rendah, dan memberikan pendidikan yang berorientasi sebagai ilmu pengetahuan agama Islam dan dijadikan titik pusat mencapai rentan waktu pendidikan selama tiga tahun. c). Madrasah lanjutan tingkat tinggi atau Aliyah, merupakan tempat untuk siswa diberikan pendidikan keilmuan agama Islam selama tiga tahun.

Ketika peraturan itu belum terjadi, tindakan pembaruan madrasah pada tahap awal telah dilaksanakan oleh Kementrian Keagamaan yakni yang diarahkan supaya bisa terdeteksi sebagai pelaksana wajibnya pembelajaran. Hal ini telah tertulis dalam undang-undang pasal 10 ayat 2 tahun 1950 no 4 mengenai Dasar-dasar Pendidikan dan Pengajaran di sekolah. Dengan begitu, pemerintah mengharapkan supaya madrasah yang telah terakui dan terpenuhi syaratnya untuk melaksanakan keutamaan belajar wajib sudah sudah masuk daftar Kementrian Keagamaan. Hal ini supaya dapat mendaftar ketentuan pokok merupakan, madrasah dalam cakupan wajib mengaplikasikan ajaran agama sebagai pembelajaran inti minimal 6 jam seminggu, secara

${ }^{9}$ Hasbullah, Sejarah Pendidikan Islam di Indonesia, h. 177. 
berkala disamping mata pelajaran menyeluruh. ${ }^{10}$ Semua dilakukan di dalam peningkatan mutu madarasah melalui SKB 3 Menteri.

Upaya dalam meningkatkan taraf madrasah terlihat semakin bergulir serta mengarah ke keseluruhan sistem pendidikan tingkat nasional dalam kaitan penggalakan pembinaan. Semua ini dinilai dari siswa madrasah yang mengacu pada harapan warga Negara Indonesia untuk mendapatkan hak dalam memperoleh peluang yang sama. Peluang itu berupa kelayakan hidup dan pekerjaan, sehingga tamatan madrasah berkeinginan untuk lanjut atau beralih ke sekolah umum dimulai dari SD hingga Universitas.

Sebagai perwujudan SKB ke 3 Kementerian, implikasinya terjadi tahun 1976 Kementrian Keagamaan telah mempublikasikan perangkat pembelajaran untuk acuan yang digunakan oleh lembaga MI, MTs, ataupun MA. SKB 3 Menteri telah memberi ketetapan: (a.) Ijazah madrasah memiliki tingkat yang sama dengan sekolah umum yang setingkat. (b.) Tamatan madrasah bisa lanjut ke sekolah umum di atasnya. (c.) Murid madrasah bisa beralih pada sekolah lebih umum yang tingkatannya sama. ${ }^{11}$ Bagi pesantren yang memiliki madrasah bisa menjadi keunggulan tersendiri karena bisa memiliki Keuntungan yang dapat diperoleh dari susunan pendidikan di pesantren ataupun madrasah tersebut untuk memperoleh keilmuan keagamaan dari eksplorasi khazanah Islam klasik, meliputi perihal yang dikaji dalam kitab kuning supaya mendapatkan sciences dan sistem teknologi terapan”.

\section{Potret Sejarah Sosial Pendidikan Isalam}

Manusia adalah makhluk pendidikan yang membutuhkan peran di dalam komunitas untuk bisa saling belajar antara individu satu dengan lainnya. Kebutuhan belajar ini menumbuhkan komunitas untuk dapat menyatukan kepentingan masa depan yang berguna bagi nusa dan bangsa. Kepentingan bersama ini menumbuhkan keinginan untuk menyatukan manusia yang membutuhkan belajar di

${ }^{10}$ Ibid, h. 177.

${ }^{11}$ Ibid, h. 182. 
lingkungannya maupaun di luar lingkungannya. Di sinilah perlunya pendidikan untuk dapat mempertahankan relasi sosial. ${ }^{12}$ Pendidikan adalah kebutuhan esensial bagi manusia termasuk umat Islam dengan segala macam runtutan sejarah yang menyertainya.

Upaya pengembangan dan pembinaan madrasah berjalan terus. Di tahun 1984 telah terpublikasi Surat Keputusan Bersama (SKB) Menteri Pendidikan dan Kebudayaan dengan Kementerian Agama Nomor 299/U/1984 dan 45 mengenai susunan peresmian kurikulum sekolah umum serta madrasah. ${ }^{13}$ Maka upaya dari SKB 2 Kementerian itu muncullah kurikulum 1984 sebagai madrasah tertulis pada Keputusan Menteri Agama Tahun 1984 No 99 untuk Madrasah Ibtidaiyah, Tahun 1984 No 100 untuk Madrasah Tsanawiyah serta Tahun 1984 No 101 untuk Madrasah Aliyah. Pada akhirnya kurikulum tersebut memiliki kegunaan yang merujuk pada SKB Menteri 3 dan 2 dalam penyusunan program, bahan, ataupun tujuan pembelajaran yang dikaji. ${ }^{14}$

Strategi yang tersusun dalam muatan kurikulum 1984 meliputi: Pemprograman rencana perangkat pembelajaran di Madrasah tahun 1984, meliputi MA, MI, MTs dilaksankan sesuai aktivitas intern yang bersangkutan, kokurikuler serta ekstrakurikuler, ditinjau dari program inti ataupun rancangan pilihan. Kegiatan belajar mengajar dilakukan dengan melihat keseimbangan dari pembelajaran seseorang dengan konsep yang dikuasainya.

Hasil nilai dari proses dan pembelajaran, serta pengelolaan program. Nilai yang turun ditinjau dari kemampuan menguasai ilmu keagamaan tamatan madrasah predikat SKB 3 Menteri ditanggapi oleh pemerintah dengan menyusun Madrasah Aliyah Program Khusus. MAPK didasarkan pada Keputusan Kementerian Agama No.73 Tahun 1987. Lahirnya keputusan MAPK digagas dari tokoh H. Munawir Sjadzali, MA (yang menjabat sebagai Menteri Agama RI). Gagasan

${ }^{12}$ Choirul Mahfud. Politik Pendidikan Islam di Indonesia. Yogyakarta: Pustaka Pelajar, 2016. Juga Choirul mahfud Chinese Muslim Community Development in Contemporary Indonesia: Experiences of PITI in East Java, Studia Islamika 25 (3), 2018.

${ }^{13}$ Hasbullah, Sejarah Pendidikan Islam di Indonesia, Ibid, 184.

${ }^{14}$ Ibid, h. 185. 
beliau, menurut Mukti Ali dan Hasan didasari dari butuhnya kemahiran tenaga di ranah Keagamaan Islam yang harus tepat pada permintaan proses perubahan secara nasionalis. Oleh karena itu perlu diusahakan untuk meningkatkan kualitas pendidikan Madrasah Aliyah. Penitikberatan MAPK merujuk pada dikembangkannya dan penguasaan ilmu keagamaan tanpa pengecualian keilmuan yang umum bentuk dari perluasan wawasan.

Pada pekembangan selanjutnya, MAPK terus digalakkan dan semakin meningkat serta berkembang baik secara kualitas dan kuantitas. Berdasarkan kurikulum 1994 dari hasil realisasi UndangUndang Tahun 1989 Nomor 02 mengenai Sistem Pendidikan Nasional, perubahan nama MAPK dijadikan Madrasah Aliyah Keagamaan. ${ }^{15}$ Tahap-tahap pendidikan yang ditempuh peserta didik secara terusmenerus dan suasana menyenangkan, Hal ini sesuai dengan prinsip bahwa proses pendidikan penilaian karakter dan budaya bangsa dilaksanakan dua komponen. Kedua komponen yang saling terkait adalah guru dan siswa. Seorang guru wajib menerapkan pernyataan "tut wuri handayani" pada tiap tingkah laku yang diperlihatkan peserta didik. Melalui pernyataan tersebut, bahwa tahap dan proses pendidikan ditempuh dalam keadaan belajar yang menyenangkan dan tidak tertekan (Kementrian Pendidikan Nasional, 2010: 18).

Untuk hal ini, demi terwujudnya capaian undang-undang dan aturan pemerintah, kementerian agama telah mempublikasikan ketentuan tentang kurikulum madrasah. Ciri dari kurikulum tersebut berlaku secara menyeluruh atau nasional yang didasarkan melalui bukti otentik surat putusan Tahun 1993 Nomor 371 tentang Kurikulum Ibtidaiyah. Sedangkan, kurikulum Madrasah Aliyah tercantum dalam UU Nomor 373 Tahun 1993. Mengenai kurikulum madrasah Tsanawiyah tertulis dalam undang-undang tahun 1993 Nomer 372. ${ }^{16}$

Pusat pengembangan madrasah berorientasi dari adanya pesantren. Hal ini ditujukan supaya langkah awal dapat dilaksanakan yang merupakan adanya kelemahan madrasah sebagai syarat dalam

${ }^{15}$ Ibid, h. 187.

${ }^{16}$ Ibid, h. 190-191. 
perbaikan ditinjau dari sisi kurikulum ataupun manajemen wajib sesuai kemajuan era saat ini. Madrasah dan pesantren harus bisa dijadikan simbol perekat fenomena dualisme dan dikotomi pendidikan agama dan pendidikan umum. Rancangan penyusunan dalam lingkup madrasah di pesantren wajib diaplikasikan untuk diciptakannya out come, diharapkan terkait erat dengan keberhasilan secara pengetahuan, sikap, dan keterampilan. ${ }^{17}$

Pada dasarnya, pesantren memang lebih dulu berdiri dibandingkan dengan madrasah. Hal ini menunjukkan bahwa pendidikan di pesantren merupakan konsistensi terpenting rancangan pendidikan yang dikembangkan pada era sekarang. Dari mulanya, pesantren memang sangat memiliki pengaruh dalam pembelajaran agama muslim yang merujuk pada kitab kuning dengan murni bahasa Arab. Hal ini berbanding terbalik dari pembelajaran yang secara umum bahkan tidak dipahami. Sejalan kemajuan waktu, pesantren mulai menghadirkan konsep pembelajaran umum pada perangkat belajar yang akhirnya melahirkan modernisasi berintegrasi ilmu pengetahuan keagamaan dan reguler. Di sisi lain, kurikulum pesantren juga mencakup berbagai kemampuan dan bakat yang dimiliki untuk bekal sosial kemasyarakatan. Pondok pada pesantren adalah satu diantara kelembagaan bidang pendidikan di Indonesia yang wajib dilanjutkan serta diperiksa secara berkala mengenai tumbuh kembangnya. Ini dilakukan karena lahirnya pondok pesantren di tengah kemasyarakatan merupakan bentuk pemberdayaan dan persiapan para penerus yang mahir agama.

\section{Penutup}

Potret madrasah di Indonesia bisa terus dipahami kemajuannya dan berbagai faktor pendukungnya yang menjadi bagian bahasan utamaa sejarah sosial pendidikan Islam di nusantara. Tentu saja, peran madrasah saat ini terus menjadi perhatian pemerintah dan masyarakat, karena besarnya kontribusi dan konsistensi madrasah

${ }^{17}$ M. Syukri Ismail, Prinsip Kemanusiaan Dalam Islam, Jurnal Nur El-Islam: Jurnal Pendidikan Islam dan Sosial Keagamaan, Vol 5, No 1 (2018): (April 2018). 
yang berorientasi dunia akhirat. Lulusan madrasah dari waktu ke waktu juga luar biasa. Inilah sumbangan yang tidak bisa dianggap remeh dari sepak terjang madrasah di Indonesia.

\section{Daftar Pustaka}

Abudin Nata. Modernisasi Pendidikan Islam di Indonesia, Jakarta: UIN Jakarta Press, 2006.

Ainurrafiq dan Ahmad $\mathrm{T}$ Dawam. Manajemen Madrasah Berbasis Pesantren, Yogyakarta: Listafariska Putra, 2005.

Azyumardi Azra. Historiografi Islam Kontemporer: Wacana, Aktualitas dan Aktor Sejarah, Jakarta: Gramedia Pustaka Utama, 2002.

Choirul Mahfud. Politik Pendidikan Islam di Indonesia. Yogyakarta: Pustaka Pelajar, 2016.

, Chinese Muslim Community Development in Contemporary Indonesia: Experiences of PITI in East Java, Studia Islamika 25 (3), 2018.

Hasbullah, Sejarah Pendidikan Islam Di Indonesia: Lintasan Sejarah Pertumbuhan dan Perkembangan, Jakarta: PT. Raja Grafindo Persada, 1999.

Heru Juabdin Sada. Kebutuhan Dasar Manusia dalam Perspektif Pendidikan Islam, Al-Tadzkiyyah: Jurnal Pendidikan Islam, Vol 8, No 2 (2017).

Husni Thoyar. Pendidikan Agama Islam. Jakarta: Pusat Kurikulum dan Pembukuan, 2004.

K Yahiji, C Mahfud, J Alfin, M Koiri, Rahmawati. Chinese ways of being good Muslim: from the Cheng Hoo Mosque to Islamic education and media literacy, Indonesian Journal of Islam and Muslim Societies 8 (2), 2018: 225-252. 
Madrasah dan Sejarah Sosial ...

Kementerian Pendidikan Nasional. Pendidikan Budaya dan Karakter Bangsa Panduan Sekolah, Balitbang Puskur Jakarta, 2010.

M. Noor Syam. Filsafat Pendidikan dan Dasar Pendidikan Pancasila, Surabaya: Usaha Nasional, 1986.

Malik A Fadjar. Reorientasi Pendidikan Islam, Jakarta: Fajar Dunia, 1999.

Muhaimin, Arah Baru Pengembangan Pedidikan Islam: Pemberdayaan, Pengembangan kurikulum hingga Redefinisi Islamisasi Pengetahuan, Bandung: Nuansa, 2003.

Muhidin Dahlan. Sosialisme Religius; Suatu Jalan Keempat?, Yogyakarta: Kreasi Wacana, 2000. 